\title{
PENERAPAN TERAPI RASIONAL EMOTIF TERHADAP KEPERCAYAAN DIRI PENYANDANG DISABILITAS FISIK DI KOTA BANDUNG
}

\author{
Lumadi $^{1}$, Bambang Sugeng ${ }^{2}$, dan Sakroni ${ }^{2}$ \\ ${ }^{1}$ Balai Besar Rehabilitasi Sosial Bina Daksa Surakarta \\ ${ }^{2}$ Sekolah Tinggi Kesejahteraan Sosial \\ E-mail:mas_alum@yahoo.com
}

\begin{abstract}
The research aims to obtain an empirical description, so that able to do an analysis of Rational Emotive Therapy (RET) can increase the confidence of physically disabled persons on optimism aspect and responsibility aspect to decision and action for research subject. The research method uses quantitative with single subject design (SSD). Recording of data used is recording with direct observation. The validity test uses recording events (counting frequencies), and the reliability of measurements on the subject is done directly by relying on accuracy. Data collection techniques were conducted by interview, questionnaire and observation. The results showed that Rational Emotive Therapy (RET) performed on subjects can increase self-confidence "AG" includes aspects of optimism and aspects of responsibility. The behavioral indicators being target behavior are awkward, shy, withdrawn, sweeping, washing dishes, and feeding the animals. Intervention is done using Rational Emotive Therapy (RET) with counseling techniques. However, it is important to take a more thorough consideration in its application, because the socio-cultural background of the research subject influences the effectiveness of the strategy.
\end{abstract}

Keywords: confidence, Emotive Rational Therapy, physically disabled persons

\section{Abstrak}

Tujuan penelitian untuk memperoleh gambaran secara empiris, sehingga mampu melakukan analisis tentang Terapi Rasional Emotif (TRE) dalam meningkatkan kepercayaan diri penyandang disabilitas fisik pada aspek optimisme dan aspek tanggung jawab terhadap keputusan dan tindakan bagi subjek penelitian. Metode penelitian menggunakan kuantitatif dengan desain subjek tunggal atau Single Subject Design (SSD). Pencatatan data yang dipakai adalah pencatatan dengan observasi langsung. Uji validitas mengunakan pencatatan kejadian (menghitung frekuensi), dan reliabilitas pengukuran pada subjek dilakukan secara langsung dengan mengandalkan ketelitian. Teknik pengumpulan data dilakukan dengan wawancara, angket dan observasi. Hasil penelitian menunjukan bahwa Terapi Rasional Emotif (TRE) yang dilakukan terhadap subjek dapat meningkatkan kepercayaan diri "AG" mencakup aspek optimisme dan aspek tanggung jawab. Indikator perilaku yang dijadikan target behavior adalah canggung, malu, menarik diri, menyapu, mencuci piring, dan memberi makan ternak. Intervensi dilakukan menggunakan Terapi Rasional Emotif (TRE) dengan teknik konseling. Meskipun demikian penting untuk dilakukan pertimbangan yang lebih seksama dalam penerapannya, karena latar sosial budaya subjek penelitian, mempengaruhi faktor keefektifan strategi tersebut.

Kata kunci: kepercayaan diri, penyandang disabilitas fisik, Terapi Rasional Emotif 


\section{Pendahuluan}

Penyandang disabilitas yang merupakan bagian dari warga negara yang memiliki hakhak dan kedudukan yang sama sebagai manusia bermartabat luhur meskipun penyandang disabilitas memiliki keterbatasan. Di samping itu penyadang disabilitas juga memiliki hak dan kewajiban yang sama dalam segala aspek kehidupan dan penghidupan sebagai warga negara. Hal ini dinyatakan dalam Undang-Undang R.I Nomor 11 Tahun 2009 Pasal 1, tentang ketentuan-ketentuan pokok kesejahteraan sosial yaitu setiap Warga Negara berhak atas kesejahteraan sosial yang sebaik-baiknya dan berkewajiban untuk sebanyak-banyaknya ikut berpartisipasi dalam usaha-usaha kesejahteraan sosial.

Undang-Undang tersebut perlu untuk diusahakan agar penyandang disabilitas dapat ikut serta berperan secara aktif dan kreatif mengembangkan kemampuan diri di dalam hidup bermasyarakat. Penyandang disabilitas menghadapi masalah yang lebih kompleks dibandingkan manusia pada umumnya, terlebih karena masalah khusus akibat disabilitas yang dimiliki. Permasalahan khusus yang dihadapi tidak sekedar masalah fisik saja melainkan secara psikis atau mental. Pandangan masyarakat yang masih memandang sebelah mata terhadap penyandang disabilitas menyebabkan kurang percaya diri, minder, dan merasa tidak berguna. Dampak dari kurang percaya diri mengakibatkan aktualisasi penyandang disabilitas menjadi terhambat, pesimistis, khawatir dan ragu-ragu menentukan pilihan dan takut bersaing dengan orang lain. Permasalahan penyandang disabilitas fisik bukan hanya mengenai masalah sulitnya mobilitas, tetapi juga permasalahanpermasalahan yang menyangkut kondisi psikososialnya.

Pandangan masyarakat mengenai ketergantungan penyandang disabilitas fisik dapat menyebabkan penyandang disabilitas fisik menjadi kurang percaya diri dan cenderung menarik diri. Pemahaman ini sangat diperlukan bagi masyarakat bahwa penyandang disabilitas mempunyai hak yang sama, sehingga tidak harus adanya perbedaan perlakuan. Berangkat dari gejala masalah tersebut peneliti mengidentifikasi masih terdapat pernyataan-pernyataan klien menunjukkan dan memandang dirinya sebagai penyandang disabilitas fisik yang belum bisa menerima keadaan dengan kondisinya, merasa gagal hidup, menjadi orang yang tidak berguna, khawatir terhadap masa depan, merasa tidak memiliki kemampuan, malu untuk bergaul dengan lingkungannya, dan pasrah terhadap dirinya, sehingga perlu dibantu untuk mengatasi permasalahannya. Harapan peneliti dapat meningkatkan kepercayaan diri dengan mengembangkan kemampuan dirinya, sehingga dapat beraktualisasi diri baik dengan teman-teman sebaya maupun dimasyarakat dan dapat menjalankan keberfungsian sosialnya. Kepercayaan diri akan menjadi modal bagi penyandang disabilitas, karena keyakinan untuk memampukan segala kelebihan dan kemampuan yang dimiliki mendorong seorang penyandang disabilitas mencapai tujuan yang diinginkan. Kepercayaan diri yang rendah akan memiliki pengaruh negatif terhadap penyandang disabilitas.

Kurangnya rasa percaya diri akan meragukan kemampuan diri sendiri dan cenderung untuk mempersepsikan segala sesuatu dari sisi negatif, sehingga menjadi bibit ketegangan, khususnya pada waktu menghadapi permasalahan sehingga ketegangan tersebut berakhir pada kegagalan. Berdasarkan realitas tersebut, maka dibutuhkan sebuah strategi konseling yang sesuai dalam menangani permasalahan kepercayaan diri bagi penyandang disabilitas fisik. Peneliti merespon kebutuhan penelitian ini dengan menerapkan terapi rasional emotif. Terapi rasional emotif digunakan oleh peneliti dalam melakukan intervensi terhadap klien dengan alasan bahwa, terapi ini merupakan perpaduan antara terapi kognitif dan terapi perilaku sehingga sesuai untuk di implementasikan terhadap penyandang disabilitas fisik yang mengalami gangguan kepercayaan diri. Terapi 
kognitif diharapkan dapat mengubah pemikiran yang ada pada diri klien (yang negatif menjadi positif), sedangkan terapi perilaku yaitu untuk mengubah kebiasaan atau perilaku-perilaku yang negatif. Harapan peneliti dalam menggunakan Terapi Rasional Emotif adalah dapat membantu mengatasi permasalahan kurang percaya diri penyandang disabilitas fisik.

Rumusan masalah penelitian, yaitu: "Apakah penerapan terapi rasional emotif berpengaruh dalam meningkatkan kepercayaan diri penyandang disabilitas fisik di Kelurahan Karang Pamulang Kecamatan Mandalajati Kota Bandung”. Selanjutnya rumusan masalah tersebut di rinci kedalam sub-sub permasalahan sebagai berikut: 1) Apakah Terapi Rasional Emotif dapat meningkatkan Optimis diri bagi Penyandang disabilitas fisik? 2) Apakah Terapi Rasional Emotif dapat meningkatkan tanggung jawab terhadap keputusan dan tindakan diri Penyandang disabilitas fisik?

Hipotesis utama dalam penelitian ini adalah Terapi Rasional Emotif dapat meningkatkan kepercayaan diri. Selanjutnya sub hipotesis sebagai berikut:

1. Terapi Rasional Emotif dapat
meningkatkan Optimis diri bagi
Penyandang disabilitas fisik di Kelurahan
Karang Pamulang.

2. Terapi Rasional Emotif dapat meningkatkan tanggung jawab terhadap keputusan dan tindakan diri bagi Penyandang disabilitas fisik di Kelurahan Karang Pamulang.

World Health Organization (WHO) mendefinisikan disabilitas menjadi 3 bagian yaitu: 1) Impairment; kehilangan atau keabnormalan struktur atau fungsi psikologis, fisik atau anatomi. 2) Disability; keterbatasan kemampuan atau ketidakmampuan (akibat dari impairment) untuk melakukan kegiatan yang dianggap normal berkaitan dengan usia dan masyarakat dimana seseorang tersebut tinggal.

3) Handicap; ketidakberuntungan yang dialami seseorang (akibat impairment dan disability), yang membatasi atau mengahalangi pemenuhan peran yang sebenarnya normal bagi orang tersebut. Berdasarkan ketiga aspek definisi menurut WHO tersebut dapat disimpulkan bahwa impairment mencakup dimensi fisik, disability mencakup dimensi aktivitas personal dalam aktivitas sehari-hari, sedangkan handicap mencakup dimensi peranan sosial. Istilah ini kemudian diakomodir dalam Undang-Undang Nomor 8 Tahun 2016 tentang Penyandang Disabilitas. Menurut Undang-Undang Nomor 8 Tahun 2016 (Bab 1 Pasal 1), penyandang disabilitas adalah:

"Setiap orang yang mengalami keterbatasan fisik, intelektual, mental dan/atau sensorik dalam jangka waktu lama yang dalam berinteraksi dengan lingkungan dapat mengalami hambatan dan kesulitan untuk berpartisipasi secara penuh dan efektif dengan warga negara lainnya berdasarkan kesamaan hak".

Undang-Undang ini telah menggunakan istilah disabilitas. Meskipun Undang-Undang tersebut telah menggunakan istilah penyandang disabilitas, namun masih ada Undang-Undang maupun peraturan pemerintah serta literatur-literatur yang menggunakan istilah penyandang cacat, kecacatan, ketunaan. Begitu pula di lembagalembaga maupun instansi seperti panti masih menggunakan istilah lama. Disabilitas ini terdapat beberapa jenis, yaitu disabilitas fisik, disabilitas mental serta disabilitas fisik dan mental. Pengelompokkan disabilitas berdasarkan jenis serta kategori ini dapat mempermudah berbagai pihak dalam memberikan perlakuan khusus kepada penyandang disabilitas.

Menurut Willis (dalam Nur Ghufron \& Rini Risnawati, 2010:34) kepercayaan diri adalah keyakinan bahwa seseorang mampu menanggulangi suatu masalah dengan situasi terbaik dan dapat memberikan sesuatu yang menyenangkan bagi orang lain. Lautser (dalam Nur Ghufron \& Rini Risnawati, 2010:34) mendefinisikan kepercayaan diri diperoleh dari pengalaman hidup. Kepercayaan diri merupakan salah satu aspek kepribadian yang 
berupa keyakinan akan kemampuan diri seseorang sehingga tidak terpengaruh oleh orang lain dan dapat bertindak sesuai kehendak, gembira, optimis, cukup toleran, dan bertanggung jawab. Lautser juga menambahkan bahwa kepercayaan diri berhubungan dengan kemampuan melakukan sesuatu yang baik. Anggapan seperti ini membuat individu tidak pernah menjadi orang yang mempunyai kepercayaan diri yang sejati. Bagaimanapun kemampuan manusia terbatas pada sejumlah hal yang dapat dilakukan dengan baik dan sejumlah kemampuan yang dikuasai. Anthony (dalam Nur Ghufron \& Rini Risnawati, 2010:34) berpendapat bahwa kepercayaan diri merupakan sikap pada diri seseorang yang dapat menerima kenyataan, dapat mengembangkan kesadaran diri, berpikir positif, memiliki kemandirian, dan mempunyai kemampuan untuk memiliki serta mencapai segala sesuatu yang diinginkan. Kumara (dalam Nur Ghufron \& Rini Risnawati, 2010:34) menyatakan bahwa kepercayaan diri merupakan ciri kepribadian yang mengandung arti keyakinan terhadap kemampuan diri sendiri. Berdasarkan penjelasan tersebut dapat disimpulkan bahwa kepercayaan diri adalah keyakinan untuk melakukan sesuatu pada diri subjek sebagai karakteristik pribadi yang di dalamnya terdapat keyakinan akan kemampuan diri, optimis, objektif, bertanggung jawab, rasional, dan realistis.

Lautser (dalam Nur Ghufron \& Rini Risnawati, 2010:36), aspek-aspek kepercayaan diri antara lain: 1) Keyakinan kemampuan diri, yaitu sikap positif seseorang tentang dirinya. Ia mampu secara sungguh-sungguh akan apa yang dilakukannya. 2) Optimis, yaitu sikap positif yang dimiliki seseorang yang selalu berpandangan baik dalam menghadapi segala hal tentang diri dan kemampuannya. 3) Objektif, yaitu orang yang memandang permasalahan atau sesuatu sesuai dengan kebenaran yang semestinya, bukan menurut kebenaran pribadi atau menurut dirinya sendiri. 4) Bertanggungjawab, yaitu kesediaan seseorang untuk menanggung segala sesuatu yang telah menjadi konsekuensinya. 5)
Rasional dan Realitas, yaitu analisis terhadap sesuatu masalah, hal, dan kejadian dengan menggunakan pemikiran yang dapat diterima oleh akal dan sesuai dengan kenyataan.

Albert Ellis mulai mengembangkan sebuah pendekatan baru, yang dinamakannya terapi rasional (juga disebut sebagai terapi rasionalemotif), yang meperlakukan para subjek dengan menantang dan mengubah keyakinankeyakinan irasional mereka. Ellis pertamatama menampilkan pendekatan baru ini pada tahun 1957 dikonvensi tahunan American Psychological Association. Tidak lama setelahnya, Ellis (1957) mampu mendemonstrasikan secara signifikan keefektifan yang lebih besar dengan pendekatan ini dari pada menggunakan pendekatan-pendekatan psikoanalisis. Terapi rasional-emotif merupakan salah satu terapi yang berasal dari pendekatan kognitif. Terapi ini lebih banyak kesamaannya dengan terapiterapi yang berorientasi kognitif-tingkah lakutindakan dalam arti menitikberatkan berpikir, menilai, memutuskan, menganalisis, dan bertindak. Terapi rasional-emotif sangat direktif serta lebih banyak berurusan dengan dimensi-dimensi pikiran daripada dengan dimensi-dimensi perasaan. Lebih lanjut, Corey (2010:244) mengatakan terapi rasional emotif (TRE) berasumsi bahwa karena keyakinankeyakinan, dan nilai-nilai irasional orangorang yang berhubungan secara kausal dengan gangguan-gangguan emosional, dan behaviornya, maka cara yang paling efisien untuk membantu orang-orang itu dalam membuat perubahan-perubahan kepribadiannya adalah secara langsung dengan filsafat hidup mereka sendiri, menerangkan kepada mereka bagaimana gagasan-gagasan mereka sampai menjadikan mereka terganggu, menyerang gagasan-gagasan irasional mereka di atas dasar-dasar logika, dan mengajari mereka bagaimana berfikir secara logis dan karenanya mendorong mereka untuk mampu mengubah atau menghapus keyakinankeyakinan irasionalnya. Jadi terapi rasional emotif (TRE) mengkonfrontasikan para subjek dengan keyakinan-keyakinan irasionalnya serta menyerang, menantang, 
mempertanyakan, dan membahas keyakinankeyakinan yang irasional itu. Terapi Rasional Emotif (TRE) telah banyak diterapkan untuk pengobatan kecemasan, permusuhan, gangguan karakter, gangguan psikotik, dan depresi.

Corey (2010:238) menjelaskan bahwa proses terapeutik terdiri atas penyembuhan irasionalitas dengan rasionalitas. Karena individu pada dasarnya adalah makhluk rasional dan karena sumber ketidakbahagiaannya adalah irasionalitas, maka individu bisa mencapai kebahagiaan dengan belajar berpikir rasional. Proses terapi, karenanya, sebagian besar adalah proses belajar-mengajar. Untuk mencapai tujuan tersebut di atas, Ellis (dalam Corey, 2010:246) menyebutkan bahwa terapis memiliki tugas-tugas yang spesifik, yaitu: 1) Langkah pertama adalah menunjukkan kepada subjek bahwa masalah yang dihadapinya berkaitan dengan keyakinan-keyakinan irasionalnya, menunjukkan bagaimana subjek mengembangkan nilai-nilai dan sikapsikapnya, dan menunjukkan secara kognitif bahwa subjek telah memasukkan banyak "keharusan", "sebaiknya", dan semestinya". Subjek harus belajar memisahkan keyakinankeyakinannya yang rasional dari keyakinankeyakinan irasionalnya. Agar subjek mencapai kesadaran, terapis berfungsi sebagai kontrapropogandis yang menantang propaganda yang mengalahkan diri yang oleh subjek pada mulanya diterima tanpa ragu sebagai kebenaran. Terapis mendorong, membujuk, dan suatu saat bahkan memerintah subjek agar terlibat dalam kegiatan- kegiatan yang akan bertindak sebagai agen-agen kontra propaganda. 2) Langkah yang kedua adalah membawa subjek ke seberang tahap kesadaran dengan menunjukkan bahwa dia sekarang mempertahankan gangguan-gangguan emosional untuk tetap aktif dengan terus-menerus berpikir secara tidak logis dan dengan mengulang-ulang kalimat-kalimat yang mengalahkan diri dan yang mengekalkan pengaruh masa kanak-kanak. Dengan perkataan lain, karena subjek tetap mereindoktrinasi diri, maka dia bertanggung jawab atas masalah-masalahnya sendiri.
Terapis tidak cukup hanya menunjukkan kepada subjek bahwa subjek memiliki prosesproses yang tidak logis, sebab subjek cenderung mengatakan, "Sekarang saya mengerti bahwa saya memiliki ketakutan akan kegagalan dan bahwa ketakutan ini berlebihan dan tidak realistis. Sekalipun demikian, saya tetap merasa takut gagal!" 3) Langkah yang ketiga, yakni berusaha agar subjek memperbaiki pikiran-pikirannya dan meninggalkan gagasan-gagasan irasionalnya. TRE berasumsi bahwa keyakinan-keyakinan yang tidak logis itu berakar dalam sehingga biasanya subjek tidak bersedia mengubahnya sendiri. Terapis harus membantu subjek untuk memahami hubungan antara gagasan-gagasan yang mengalahkan diri dan filsafat-filsafatnya yang tidak realistis yang menjurus pada lingkaran setan proses penyalahan diri. 4) Langkah keempat: terakhir dalam proses terapeutik adalah menantang subjek untuk mengembangkan filsafat-filsafat hidup yang rasional sehingga subjek bisa menghindari kemungkinan menjadi korban keyakinankeyakinan yang irasional. Menangani masalah-masalah atau gejala-gejala yang spesifik saja tidak menjamin bahwa masalahmasalah lain tidak akan muncul. Yang kemudian diharapkan adalah terapis menyerang inti pikiran irasional dan mengajari subjek bagaimana menggantikan keyakinankeyakinan dan sikap-sikap yang irasional dengan yang rasional.

\section{Tujuan}

Penelitian ini bertujuan untuk memperoleh bukti empiris tentang pengaruh Terapi Rasional Emotif dalam meningkatkan kepercayaan diri penyandang disabilitas. Juga penelitian ini bertujuan untuk melakukan analisis tentang:

1. Terapi Rasional Emotif dapat meningkatkan optimis diri bagi penyandang disabilitas fisik di Kelurahan Karang Pamulang.

2. Terapi Rasional Emotif dapat meningkatkan tanggung jawab terhadap keputusan dan tindakan diri bagi Penyandang disabilitas fisik di Kelurahan Karang Pamulang. 


\section{Metode}

Penelitian ini menggunakan metode kuantitatif dengan desain subjek tunggal (Single Subject Design), dimana $\mathrm{N}=1$. Desain subjek tunggal yang digunakan dalam penelitian ini menggunakan model A-B-A, dimana: 1) Fase A, disebut juga fase baseline (A1) adalah gambaran kondisi awal sebelum intervensi dalam keadaan alamiah sebagai dasar untuk pengamatan dan penilaian pada variable terikat. Vonk, dkk (2007;159-160) mengatakan bahwa dalam keadaan tertentu untuk mengukur baseline dapat menggunakan informasi dari orang yang signifikan (significant others) dalam lingkungan klien. 2) Fase B, disebut juga fase intervensi. Dalam penelitian ini peneliti melakukan intervensi dengan menggunakan Terapi Rasional Emotif. Pada fase ini perubahan sebagai hasil dari intervensi diukur dan dimonitoring sehingga mendapatkan target perilaku yang sesuai dengan yang telah direncanakan, dan memeliharannya menjadi stabil dalam diri subjek, dan 3) Fase A2, merupakan fase hasil atau fase akhir. Pada tahap ini peneliti melakukan asesmen kembali dan observasi lanjutan terhadap pelaksanaan Terapi Rasional Emotif. Hal ini dimaksudkan untuk menarik kesimpulan adanya hubungan fungsional antara variable bebas dengan variable terikat. Lamanya waktu yang diperlukan pada fase baseline dan perlakuan adalah sama. Sunanto, dkk (2005:60) mengatakan bahwa pengukuran dan pengumpulan data pada kondisi baseline (A1) dan fase intervensi dilakukan secara kontinyu sekurang-kurangnya 3 atau 5 kali. Dalam penelitian ini digunakan waktu yang seimbang yaitu 3 kali pengukuran. Pengumpulan data pada Single Subject Design $(S S D)$ bersifat kuantitatif karena merujuk kepada frekuensi dari perilaku tertentu sebagai target perilaku, namun mengingat masalah perilaku sangat dipengaruhi latar belakang budaya, keluarga dan lingkungan sosial, maka penelitian juga berupaya melakukan pendalaman secara komprehensif sehingga membutuhkan dukungan data yang bersifat kualitatif.
Dalam penelitian eksperimen, analisis data pada umumnya menggunakan teknik statistik inferensial sedangkan pada penelitian eksperimen dengan subjek tunggal menggunakan statistik deskriptif. Analisis data pada penelitian dengan subjek tunggal terfokus pada data individu daripada data kelompok. Meskipun demikian data kelompok kadang-kadang juga digunakan. Analisis ada tidaknya efek variabel bebas atau intervensi terhadap variabel terikat atau perilaku sasaran (target behavior) dalam eksperimen dengan subjek tunggal disamping berdasarkan analisis statistik juga dipengaruhi disain yang digunakan. Tujuan utama analisis data dalam penelitian di bidang modifikasi perilaku adalah untuk mengetahui efek atau pengaruh intervensi terhadap perilaku sasaran yang ingin diubah. Metode analisis yang digunakan lazim disebut inspeksi visual dimana analisis dilakukan dengan melakukan pengamatan langsung terhadap data yang telah ditampilkan dalam grafik. Analisis inspeksi visual ini terkesan tidak ilmiah dan subjektif dibandingkan dengan cara analisis yang lain, misalnya analisis dengan statistik inferensial.

Meskipun demikian, analisis dengan inspeksi visual ini tidak dilakukan dengan sembarang dan pengamatan semata, tetapi diperlukan perhitungan tertentu yang dapat dipertanggungjawabkan secara ilmiah. Ada beberapa komponen penting yang dianalisis dengan cara ini, yaitu; 1) Panjang Kondisi, merupakan banyaknya data dan sesi yang ada pada suatu kondisi atau fase. Semakin banyak data dan sesi menggambarkan bahwa dalam kondisi atau fase tersebut dilakukan dalam waktu yang lebih lama. Seberapa banyak data yang harus dikumpulkan atau berapa sesi pengukuran dilakukan pada setiap kondisi tidak ada batasan secara jelas tetapi sangat tergantung pada perilaku atau variabel apa yang diukur dan bentuk intervensi yang di berikan. Meskipun demikian yang menjadi pertimbangan utama bukanlah banyaknya data tersebut melainkan tingkat kestabilan dan kecenderungan arah grafiknya. 2) Tingkat (level), istilah ini digunakan untuk menunjukkan besar kecilnya perubahan data 
dan besar kecilnya tingkat stabilitas data dalam suatu kondisi. Dengan kata lain istilah level ini digunakan untuk dua kepentingan untuk menggambarkan tingkat perubahan dan stabilitas data yang masing-masing dikenal dengan terminologi level change (tingkat perubahan) dan level stability (tingkat stabilitas). Aspek kedua tentang level ini adalah tingkat perubahan (level change) yang menunjukkan berapa besar terjadinya perubahan data dalam suatu kondisi dan antar kondisi. Level change data dalam kondisi merupakan selisih antara data pertama dan terakhir. 3) Kecenderungan (trend). Penelitian di bidang modifikasi perilaku, kecenderungan (trend) arah data pada suatu grafik sangat penting untuk memberikan gambaran perilaku subjek yang sedang diteliti dengan menggunakan kombinasi antara level dan trend, peneliti dapat menetukan pengaruh intervensi yang diberikan. Kecenderungan arah grafik (trend) menunjukkan perubahan setiap jejak data dari sesi ke sesi (waktu ke waktu). Adapun teknik analisis data yang digunakan dalam penelitian ini adalah; analisis dalam kondisi dan analisis antar kondisi.

Analisis dalam kondisi adalah analisis perubahan data dalam suatu kondisi, misalnya kondisi baseline atau kondisi intervensi. Sementara komponen yang akan dianalisis dalam kondisi ini meliputi; a) Panjang Kondisi, merupakan banyaknya data dalam kondisi tersebut. Banyaknya data dalam suatu kondisi juga menggambarkan banyaknya sesi yang dilakukan pada kondisi tersebut. panjang kondisi atau banyaknya data dalam baseline tidak ada ketentuan yang pasti. Namun demikian, data dalam kondisi baseline dikumpulkan sampai data menunjukkan stabilitas dan arah yang jelas. b) Kecenderungan arah, digambarkan oleh garis lurus yang melintasi semua data dalam suatu kondisi dimana banyaknya data yang berada di atas dan di bawah garis tersebut sama banyak. Untuk membuat garis ini dapat ditempuh dengan dua metode, yaitu metode tangan bebas (freehand) dan metode belah tengah (split-midle). Metode tangan bebas yaitu membuat garis secara langsung pada suatu kondisi sedemikian rupa sehingga membelah data sama banyak yang terletak diatas dan dibawah garis tersebut. sementara metode belah tengah adalah membuat garis lurus yang membelah data dalam suatu kondisi berdasarkan median. c) Tingkat Stabilitas (level stability), menunjukkan tingkat homogenitas data dalam suatu kondisi. Adapun tingkat kestabilan data ini dapat ditentukan dengan menghitung banyaknya data yang berada di dalam rentang $50 \%$ diatas dan dibawah mean. Jika sebanyak $50 \%$ atau lebih data berada dalam rentang 50\% diatas dan dibawah mean, maka data tersebut dapat dikatakan stabil. d) Tingkat Perubahan (level change), menunjukkan besarnya perubahan antara dua data. Tingkat perubahan data ini dapat dihitung untuk data dalam suatu kondisi maupun data antar kondisi. Tingkat perubahan data dalam suatu kondisi merupakan selisih antara data pertama dengan data terakhir. Sementara tingkat perubahan data antar kondisi ditunjukkan dengan selisih antara data terakhir pada kondisi pertama dengan data pertama pada kondisi berikutnya. e) Jejak Data (data path) merupakan perubahan dari data satu ke data lain dalam suatu kondisi. Perubahan satu data ke data berikutnya dapat terjadi tiga kemungkinan, yaitu menaik, menurun, dan mendatar. Jika serentetan data dalam suatu kondisi kita telusuri jejak datanya dari yang pertama hingga yang terakhir secara umum rentetan data tersebut dapat disimpulkan menaik, mendatar atau menurun. Kesimpulan mengenai hal ini sama dengan yang ditunjukkan oleh analisis pada kecendrungan arah. f) Rentang, merupakan jarak antara data pertama dengan data terakhir. Rentang ini memberikan informasi sebagaimana yang diberikan pada analisis tentang tingkat perubahan (level change).

Analisis Antarkondisi. Analisis data antarkondisi terkait dengan komponen utama meliputi; a) Variabel yang diubah dalam analisis data antar kondisi sebaiknya variabel terikat atau perilaku sasaran difokuskan pada satu perilaku. Artinya analisis ditekankan pada efek atau pengaruh intervensi terhadap perilaku sasaran. b) Perubahan kecenderungan 
arah dan efeknya. Dalam analisis data antar kondisi, perubahan kecenderungan arah grafik antara kondisi baseline dan intervensi menunjukkan makna perubahan perilaku sasaran (target behavior) yang disebabkan oleh intervensi. c) Perubahan stabilitas dan efeknya. Stabilitas data menunjukkan tingkat kestabilan perubahan dari sederetan data. Data dikatakan stabil apabila data tersebut menunjukkan arah (mendatar, menaik, atau menurun) secara konsisten. Dalam analisis antar kondisi, kestabilan data memegang peranan penting. Misalnya, jika data pada kondisi baseline tidak stabil berarti jika data itu menaik atau menurun, namun belum dapat diyakini kenaikan atau penurunannya. Kondisi baseline yang seperti ini tidak memungkinkan peneliti melanjutkan memberikan intervensi. Untuk memulai menganalisis perubahan antar kondisi, data yang stabil harus mendahului kondisi yang akan dianalisis. d) Perubahan level data. Perubahan level data menunjukkan seberapa besar data berubah. Sebagaimana telah dijelaskan sebelumnya, tingkat (level) perubahan data antar kondisi (misalnya kondisi baseline dan intervensi) ditunjukkan selisih antara data terakhir pada kondisi baseline dan data pertama pada kondisi intervensi. Nilai selisih ini menggambarkan seberapa besar terjadi perubahan perilaku akibat sebagai pengaruh dari intervensi. e) Data yang tumpang tindih (overlap). Data yang tumpang tindih antara dua kondisi adalah terjadinya data yang sama pada kedua kondisi tersebut. data yang tumpang tindih menunjukkan tidak adanya perubahan pada kedua kondisi dan semakin banyak data yang tumpang tindih semakin menguatkan dugaan tidak adanya perubahan pada kedua kondisi.

\section{Hasil dan Pembahasan}

\section{Hasil}

1. Deskripsi Subjek Penelitian

Subjek dalam penelitian adalah "AG" berusia 25 (dua puluh lima) tahun, laki-laki, seorang penyandang disabilitas fisik dan anak kedua dari dua bersaudara. Tujuan penelitian ini adalah peningkatan kepercayaan diri terhadap "AG". Pada pembahasan awal telah dijelaskan mengenai pengertian kepercayaan diri, faktorfaktor yang mempengaruhi kepercayaan diri dan aspek-aspek kepercayaan diri. Adapun indikator kepercayaan diri yang dijadikan subjek dalam penelitian ini adalah aspek optimis dan aspek tanggung jawab.

Dalam kesehariannya "AG" termasuk sosok yang tertutup (introvet) dan tidak banyak bicara. Saat di rumah "AG" lebih sering menghabiskan waktu didalam kamar dan jarang bergaul serta berinteraksi dengan lingkungan sekitarnya. Ibunya kurang memperhatikan "AG" dalam hal bertanggung jawab terhadap pekerjaan rumah, misalnya mencuci piring, mencuci pakaian, menyapu, maupun memberi makan ternak. Di lingkungan sekitar rumah "AG" tergolong orang yang sangat pemalu dan cenderung menarik diri dibanding untuk melakukan hubungan sosial dengan teman-teman di lingkungan tempat tinggalnya. "AG" merasa orang-orang di sekitar rumah tidak akan menerima kehadirannya sehingga ia lebih memilih untuk menyendiri dirumah saja. Ia merasa sangat sulit menerima kenyataan kondisi fisiknya yang berbeda dari kebanyakan orang sekitarnya yang mana keadaan ini dianggapnya menjadi penghambat dirinya untuk beraktifitas sehari-hari maupun berinteraksi sosial secara wajar. "AG" mengakui terkadang mempunyai keinginan untuk melawan rasa malu yang berlebihan tersebut. Namun Kesadaran "AG" untuk melawan rasa malu tersebut tidak membuat dirinya berhenti dari pemikiran-pemikiran negatif terhadap dirinya maupun lingkungan sekitarnya. Suatu peristiwa yang selalu diingatnya ketika ibunya menyuruh untuk belanja di warung, "AG" mendapatkan perlakuan yang tidak mengenakkan dari sekelompok teman-teman sebayanya yang lagi nongkrong di warung tersebut. Salah satu orang yang nongkrong tersebut mengatakan "lobak gaya maneh, kalo jalan nu alus, ulah kitu” (banyak gaya kamu, kalau jalan yang bener, jangan kayak gitu), walaupun maksud orang tersebut sebatas candaan tapi bagi "AG" itu adalah perlakuan yang sulit diterima dan sangat memalukan. Berawal dari kejadian 
tersebut "AG" meyakini bahwa dirinya memang berbeda sehingga muncul pemikiranpemikiran negatif (keyakinan irasional) yang tertanam dalam dirinya.

\section{Deskripsi pelaksanaan terapi rasional} emotif

Proses pelaksanaan terapi rasional emotif dilakukan dalam empat tahap, untuk melihat tiap tahapan tersebut akan disajikan dalam bentuk analisis statistik dan visual pada subjek penelitian. Tahap I, menunjukkan kepada subjek bahwa masalah yang dihadapinya berkaitan dengan keyakinan-keyakinan irasionalnya. Pada tahap ini peneliti sekaligus berperan sebagai terapis berusaha menjelaskan tujuan dan garis besar sesi intervensi terapi rasional emotif. Agar konseli lebih memahami permasalahan yang telah dialaminya, terapis menjelaskan komponen $\mathrm{ABC}$ yang menjadi ciri khas dalam terapi rasional emotif terkait dengan permasalahan yang dialami konseli.

Dari penjelasan tersebut, konseli mulai memahami bahwa kurangnya kepercayaan diri yang dialami adalah akibat dari keyakinannya (belief) terhadap peristiwa yang dialami yaitu rasa takut yang berlebihan jika mendapat penolakan dari masyarakat. Terapis mengajak konseli untuk membedakan keyakinan irasional dan rasional. Sampai pada akhirnya konseli mengungkapkan keyakinan irasionalnya (irrational belief) yang sering mengganggu seperti "saya sangat takut ketika disuruh pergi belanja di warung, saya takut bertemu teman-teman sebaya dan akhirnya dicemooh". "saya adalah orang cacat tapi saya harus mampu membuktikan diri agar tidak dipermalukan teman-teman". "salah satu cara agar saya terhindar dari cemoohan ya saya menutup diri di rumah".

Pada tahap II, membawa subjek ke seberang tahap kesadaran dengan menunjukkan bahwa konseli sekarang mempertahankan gangguangangguan emosional untuk tetap aktif dengan terus menerus berpikir secara tidak logis dan dengan mengulang kalimat-kalimat yang mengalahkan diri dan yang mengekalkan pengaruh pada masa kanak-kanak. Pada tahap ini terapis memberikan kesempatan kepada konseli untuk menanyakan tentang hal yang tidak dimengerti pada sesi sebelumnya. Konseli bertanya "cara yang mudah untuk membedakan keyakinan irasional dan rasional itu seperti apa?'”. Terapis menjelaskan kembali dan memberikan contoh lembar yang berisi daftar keyakinan irasional dan rasional agar konseli lebih memahaminya. Terapis menambahkan penjelasan tentang konsep DEF dalam terapi rasional emotif. Dimulai dari D (disputing) melawan keyakinan irasional agar konseli dapat merasakan E (effect) positif dari keyakinan yang rasional sehingga dapat menemukan perasaan baru yang termanifestasikan dengan $\mathrm{F}$ (feeling).

Pada tahap III, mengusahakan agar subjek memperbaiki pikiran-pikirannya dan meninggalkan gagasan-gagasan irasionalnya. Pada tahap ini terapis menjelaskan pikiran irasional yang menjadi akar permasalahan konseli dapat diganti dengan pikiran yang lebih rasional sehingga kepercayaan diri meningkat. Konseli diajarkan dan didorong untuk menantang keyakinan irasionalnya dan mengubahnya menjadi keyakinan rasional. Dengan pertanyaan "apakah orang cacat itu selalu dinilai dari sisi keterbatasan fisiknya saja, tidak adakah penilaian dengan sisi lainnya?", "apakah karena keterbatasan fisikmu lantas membuatmu merasa tidak memiliki kemampuan yang lain?"(disputing). Konseli menjawab dengan pernyataan "ya enggak sih pak,,,,". Dari pernyataan yang diungkapkan konseli tersebut, terapis berusaha menunjukkan ketidakrasionalan pemikirannya dengan memberikan contoh-contoh ungkapan keyakinan irasional.

Setelah konseli mulai menemukan ungkapan yang tepat untuk mengubah keyakinan irasionalnya maka selanjutnya konseli didorong untuk menyusun rencana cara meningkatkan kepercayaan diri. setelah itu konseli didorong untuk melakukan tindakan yang ia hindari (desensitization). Konseli mengungkapkan "sampai kapanpun saya tidak akan bisa berhasil kalau saya sendiri tidak percaya dengan kemampuan saya". Terapis 
menanggapi dengan pernyataan "lantas apa yang akan kamu lakukan?". Konseli mengungkapkan "yaahh terlebih dahulu saya berusaha menghargai diri saya dulu, saya yakin bisa, insyaallah saya nantinya akan bisa melakukan hal yang biasanya saya tidak berani lakukan". Dari ungkapan konseli, terapis menyimpulkan bahwa sudah ada niatan untuk berubah yang ingin dilakukan oleh konseli, sehingga terapis terus mendorong konseli agar mampu meningkatkan optimisme dan bertanggung jawab atas tugas-tugas hidupnya. Konseli mampu menyusun rencana yang ditunjukkan dengan pernyataan "saya akan mengesampingkan rasa malu pak, saya tidak akan pernah tau arti kesuksesan jika saya takut gagal dan tidak mencoba”.

Pada tahap IV, terakhir dalam proses terapeutik adalah menantang konseli untuk mengembangkan filsafat-filsafat hidup yang rasional sehingga konseli bisa menghindari kemungkinan menjadi korban keyakinankeyakinan yang irasional. Setelah dihadapkan pada situasi-situasi yang ia hindari dan konseli telah mencobanya meskipun belum berhasil, maka terapis mendorong konseli untuk menggunakan kalimat yang lebih positif dalam mengekspresikan keyakinan rasionalnya (semantic precision). Pada pertemuan sebelumnya konseli diberikan tugas untuk menghadapi situasi yang ia takuti, dan ia gagal melalui itu. Untuk memotivasi dirinya, terapis mengajarkan kepada konseli agar tetap meneguhkan hati untuk mencoba. Mengganti kata "tidak berani" menjadi kata "belum berani".

Ketika konseli sudah mampu merespon segala kejadian dengan kalimat positif meskipun mengalami kegagalan, maka selanjutnya terapis mengajak konseli untuk berpikir logis dengan tujuan agar konseli mampu mempertahankan keyakinan rasionalnya serta meminimalisir terjadinya perilaku yang dapat merugikan diri. Secara umum proses terapeutik tahap empat berjalan dengan lancar sesuai dengan langkah-langkah terapi rasional emotif. Konseli sudah mampu berpikir secara logis dalam menyikapi setiap kejadian yang dialami.
Kemampuan yang diperoleh konseli selama sesi intervensi membuat konseli mampu mengidentifikasi keyakinan irasional sebagai akar permasalahan rendahnya kepercayaan diri yang dialaminya. Terapis mengajak konseli untuk menuliskan tiga daftar tentang keyakinan irasional pada selembar kertas yang digunakan sebagai pengingat ketika nanti dihadapkan pada permasalahan yang sama (self statement). Berdasarkan hasil lembar kerja yang diisi oleh konseli mengungkapkan keyakinan rasional yang ia kemukakan adalah "gagal dalam melakukan suatu hal bukan berarti bodoh atau tidak bisa melainkan belum bisa", tidak semua orang cacat memperoleh kesempatan terbatas dalam berkarya", "menerima diri secara positif dan selalu berbenah diri untuk menjadi lebih baik adalah salah satu cara untuk meningkatkan kualitas diri saya". Terapis menganggap bahwa konseli sudah mampu menyelesaikan masalahnya sendiri ketika menghadapi peristiwa yang sama, oleh karena itu konseli didorong untuk menjadi terapis bagi dirinya sendiri dengan bekal pemahaman selama proses intervensi. Konseli mengakui bahwa dirinya merasa lebih percaya diri dan nyaman dalam menjalani aktifitas sehari-hari dengan kemampuan yang dimiliki (new feeling).

\section{Pembahasan}

Kecenderungan tingkat kepercayaan diri yang dialami "AG", ditunjukkan oleh sejumlah indikator kepercayaan diri melalui aspek optimis dan tanggung jawab. Semakin tinggi indikator perilaku optimis maka semakin rendah tingkat kepercayaan dirinya, dan semakin rendah indikator perilaku tanggung jawab yang ditunjukkan maka semakin rendah pula tingkat kepercayaan diri yang dialami "AG". Gambaran kondisi awal kepercayaan diri "AG" berdasarkan hasil pencatatan kejadian dengan observasi langsung dapat dilihat dalam tabel 1 di bawah ini. Tabel 1 menggambarkan hasil pengamatan terhadap target behavior yang dilakukan secara terus menerus selama tiga hari berturut-turut. Pada tanggal 15 Mei 2017 terjadinya perilaku sasaran (target behavior) pada aspek optimis 
sebanyak 3 (tiga) kali, sedangkan pada aspek tanggung jawab sebanyak 1 (satu) kali. Pada tanggal 16 Mei 2017 terjadinya perilaku sasaran pada aspek optimis sebanyak 2 (dua) kali, sedangkan pada aspek tanggung jawab sebanyak 1 (satu) kali. Pada tanggal 17 Mei 2017 terjadinya perilaku sasaran pada aspek optimis sebanyak 3 (tiga) kali, sedangkan pada aspek tanggung jawab tidak ada (tidak terjadi).

Tabel 1

Gambaran Kepercayaan Diri "AG" sebelum Intervensi (baseline)

\begin{tabular}{|c|c|c|c|c|}
\hline $\begin{array}{c}\text { Tanggal/ } \\
\text { Waktu } \\
(06.00-17.00)\end{array}$ & $\begin{array}{c}\text { Aspek Percaya } \\
\text { Diri }\end{array}$ & Indikator & $\begin{array}{l}\text { Tally Terjadinya } \\
\text { Target Behavior }\end{array}$ & $\begin{array}{c}\text { Total } \\
\text { Kejadian }\end{array}$ \\
\hline \multirow[t]{2}{*}{15 Mei 2017} & Optimis & $\begin{array}{l}\text { Terlihat canggung, malu, } \\
\text { dan menarik diri }\end{array}$ & III & 3 \\
\hline & Tanggung Jawab & $\begin{array}{l}\text { Menyapu, mencuci piring, } \\
\text { memberi makan ternak }\end{array}$ & $I$ & 1 \\
\hline \multirow[t]{2}{*}{ 16 Mei 2017} & Optimis & $\begin{array}{l}\text { Terlihat canggung, malu, } \\
\text { dan menarik diri }\end{array}$ & II & 2 \\
\hline & Tanggung Jawab & $\begin{array}{l}\text { Menyapu, mencuci piring, } \\
\text { memberi makan ternak }\end{array}$ & $I$ & 1 \\
\hline \multirow[t]{2}{*}{17 Mei 2017} & Optimis & $\begin{array}{l}\text { Terlihat canggung, malu, } \\
\text { dan menarik diri }\end{array}$ & III & 3 \\
\hline & Tanggung Jawab & $\begin{array}{l}\text { Menyapu, mencuci piring, } \\
\text { memberi makan ternak }\end{array}$ & - & 0 \\
\hline
\end{tabular}

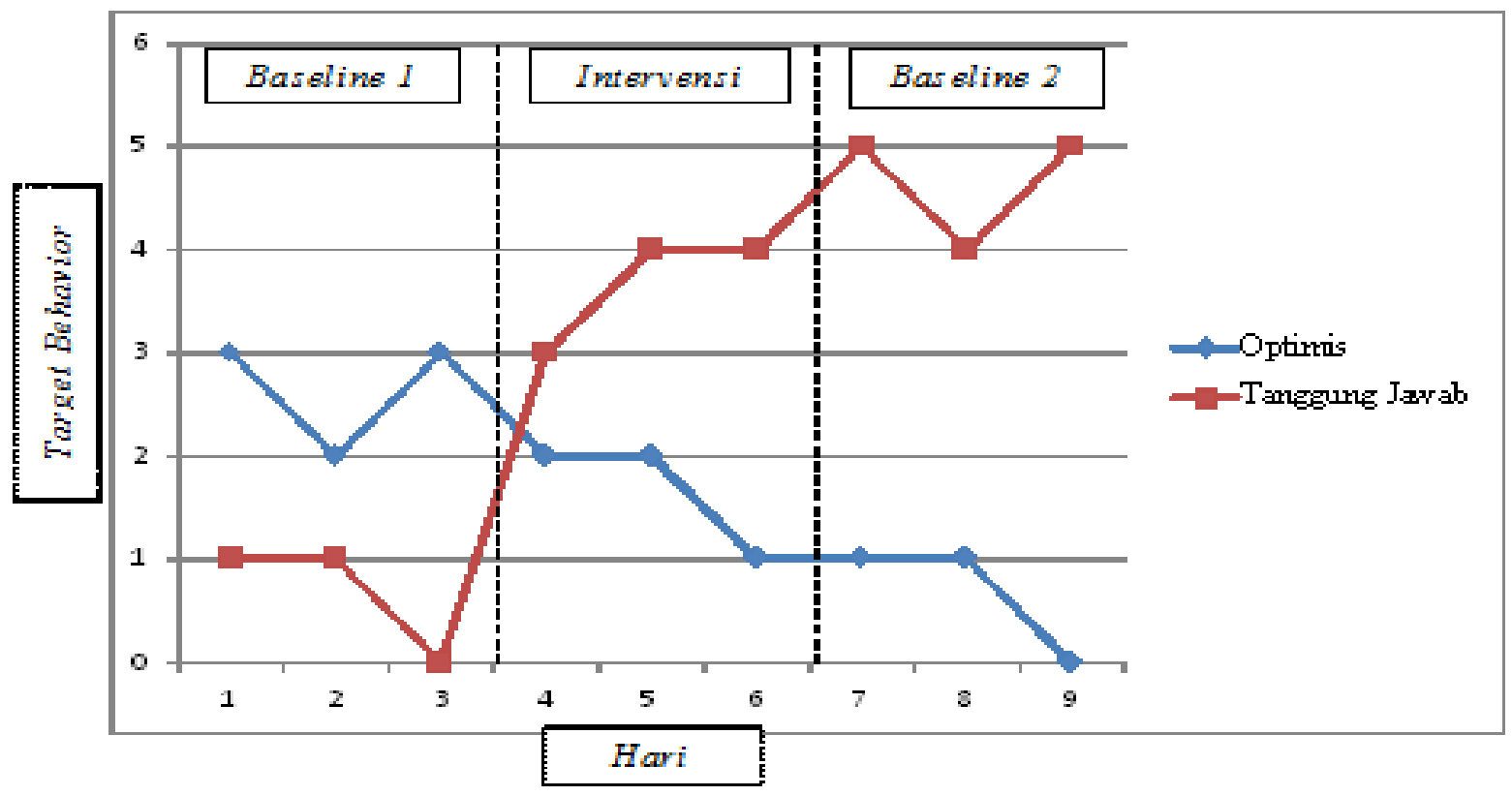

Gambar 1

Perbandingan Kondisi Kepercayaan Diri "AG" 
Kondisi awal kepercayaan diri "AG" menunjukkan kriteria rendah dibandingkan dengan kondisi setelah mendapatkan intervensi, hal ini menegaskan bahwa terapi rasional emotif secara empiris terbukti efektif untuk meningkatkan kepercayaan diri. Keefektifan terapi rasional emotif ditunjukkan dengan meningkatnya kepercayaan diri melalui aspek optimis dan tanggung jawab. Konseli adalah penyandang disabilitas fisik yang termasuk kategori masa remaja. Masa remaja merupakan masa yang memiliki posisi kurang jelas karena bukan termasuk golongan anak-anak namun juga bukan termasuk golongan orang dewasa.masa remaja berada diantara masa anak dan dewasa. Pada masa ini, remaja belum mampu menguasai fungsi fisik dan psikisnya. Remaja umumnya masih berada dibangku sekolah menengah dan perguruan tinggi (Monks, 2006, hlm. 258259). Persepsi diri "AG" umumnya mengalami tekanan yang besar pada aspek psikologis sehingga dimungkinkan terjadinya kemurungan, kecemasan dan sensitivitas. Hal tersebut bersumber dari kenyataan keadaan fisiknya yang mengalami kecacatan sehingga secara khusus berpengaruh pada pembentukan kepercayaan dirinya menjadi rendah.

Kepercayaan diri berkembang sepanjang rentang kehidupan. Masa yang rentan mengalami kepercayaan diri rendah adalah pada masa remaja. Fokus intervensi yakni menitikberatkan adanya perubahan dalam pola keyakinan yang dianut oleh konseli yang menjadi subjek penelitian. Keyakinan yang dianut memberikan pengaruh terhadap pembentukan kepribadian dan perilaku seharihari. Apabila "AG" mampu menilai diri secara positif dan rasional maka mengarah pada pembentukan kepercayaan diri yang tinggi. Namun sebaliknya jika "AG" menilai dirinya secara negatif dan penilaian tersebut bersumber dari keyakinan yang tidak rasional maka mengarah pada pembentukan kepercayaan diri yang rendah. Oleh sebab itu, salah satu cara untuk meningkatkan kepercayaan diri yakni melalui perubahan keyakinan terkait dengan penilaian diri. Darminto (2007) bahwa mengubah kognisi seseorang merupakan cara efektif dalam meningkatkan aspek kognitif, emosi dan perilaku. Bukan hanya situasi lingkungan yang menentukan perasaan individu, akan tetapi ditentukan juga bagaimana individu mengkonstruksikan situasi-situasi yang dihadapinya. Keyakinan irasional yang dianut oleh "AG" akan berpengaruh terhadap peristiwa yang dialami. "AG" perlu melawan atau menentang keyakinan irasional tersebut agar tidak berdampak pada pembentukan kepercayaan diri yang rendah. Ketika "AG" mampu menentang keyakinan irasional yang menjadi sumber permasalahan dalam hidupnya maka akan memunculkan perasaan atau emosi positif pada diri.

Secara umum karakteristik yang termanifestasikan dalam sifat dan sikap " $A G$ " sejalan dengan karakteristik kepercayaan diri rendah yaitu tidak memiliki keyakinan atas kemampuan diri, tidak mampu bersikap optimis, tidak mampu bersikap obyektif, tidak mampu bertanggung jawab, tidak mampu berpikir rasional dan realistis. Perubahan yang terjadi pada subjek penelitian mengarah pada peningkatan kepercayaan diri. peneliti menemukan bahwa terapi rasional emotif mampu meningkatkan kepercayaan diri pada aspek optimis dan tanggung jawab. Terdapat hubungan yang signifikan antara kepercayaan diri dengan aspek optimisme dan aspek tanggung jawab pada diri "AG". Peningkatan optimisme dan tanggung jawab "AG" dapat mengarah pada peningkatan kepercayaan diri. Peneliti juga menemukan fakta bahwa keluarga merupakan faktor penting dalam pembentukan kepercayaan diri. Keluarga merupakan lingkungan yang sangat penting dalam membentuk segala konteks perkembangan sosial dan kepribadian. Bukti pentingnya peran orang tua dalam pembentukan kepercayaan diri seperti yang dialami "AG". Dalam lingkungan keluarga konseli "AG" kurang mendapatkan perhatian dan peran dari orangtuanya, terutama ayahnya 
yang sudah meninggal sejak "AG" masih usia kanak-kanak. Pentingnya peran orang tua dalam pembentukan kepercayaan diri memiliki kontribusi yang besar, kontribusi yang dimaksud adalah keterlibatan orang tua dalam menciptakan status sosial dan ekonomi keluarga. Perkembangan kepercayaan diri dipengaruhi secara langsung oleh peran pengasuhan orang tua, selain itu peran teman sebaya dalam pergaulan sosial juga berpengaruh meskipun tidak langsung. Kedekatan orang tua terhadap "AG" juga mempengaruhi berbagai aspek lain yakni perilaku sosial "AG" terhadap lingkungan sekitarnya. Dari penjelasan yang telah dikemukakan dapat disimpulkan bahwa orang tua memberikan kontribusi yang signifikan terhadap perkembangan kepercayaan diri “AG".

\section{Simpulan}

Penerapan Terapi rasional emotif dapat meningkatkan kepercayaan diri pada aspek optimisme dan aspek tanggung jawab terhadap penyandang disabilitas fisik "AG". Ini ditunjukkan pada indikasi perbedaan yang sangat signifikan antara kondisi yang ditunjukkan sebelum diberikan intervensi dengan kondisi yang ditunjukkan setelah diberikan intervensi. Temuan ini memberikan indikasi bahwa strategi modifikasi memiliki signifikasi yang sangat tinggi untuk mengembangkan penilaian kognitif "AG" terhadap optimisme diri dan tanggung jawabnya. Kendati demikian penting untuk dilakukan pertimbangan yang lebih seksama dalam penerapannya, karena latar sosial budaya subjek penelitian, mempengaruhi faktor keefektifan strategi tersebut. Ada perbedaan yang sangat nyata, optimisme "AG" ketika kondisi sebelum diberikan intervensi dengan kondisi setelah diberikan intervensi. Optimisme "AG" lebih meningkat positif dengan ditunjukkan adanya perubahan perilaku, yang semula cenderung malu, canggung dan menarik diri menjadi percaya diri dan yakin dengan kemampuan diri yang dimilikinya. Ada perbedaan yang sangat nyata, tanggung jawab "AG" ketika kondisi sebelum diberikan intervensi dengan kondisi setelah diberikan intervensi. Kemampuan bertanggung jawab "AG" lebih meningkat dengan ditunjukkan perubahan perilaku yang semula jarang melakukan pekerjaan rumah, menjadi rajin melakukan pekerjaan rumah, antara lain Menyapu, mencuci piring, dan memberi makan ternak.

\section{Daftar Pustaka}

Corey Gerald. 2007. Teori dan Praktek Konseling dan Psikoterapi. Bandung: Refika Aditama.

Dharsana Ketut. 2014. Strategi Modifikasi Kognitif. Yogyakarta: Graha Ilmu.

Ellis Albert \& Bernard Michael E. 2006. Rational Emotive Behavioral Approaches to Childhood Disorders Theory, Practice and Research. New York: Springer Science\& Bussines Media. Inc.

H.Welianga, Ni Made Taganing K. Efektifitas Terapi Rasional Emotif (TRE) dalam Mengurangi Pikiran Tidak Rasional dan Stres pada Perempuan yang Mengalami Kekerasan dalam Rumah Tangga (KDRT). Proceeding PESAT (Psikologi, Ekonomi, Sastra, Arsitektur, dan Sipil). Jurnal Universitas Gunadarma-Depok 3 (2009).

Indari Mastuti. 2008. 50 Kiat Percaya Diri. Jakarta: Hi-Fest Publishing. Jurusan Rehabilitasi Sosial. Manual Terapi Psikososial. Bandung: Kopma STKS Bandung. 
Mappiare AT, Andi. 2010. Pengantar Konseling dan Psikoterapi. Edisi Kedua. Jakarta: PT Raja Grafindo Persada.

M.Ahmud, M.Thohir. Konseling Islam dengan Terapi Rasional Emotif Behavior untuk Mengubah Wanita Penyanyi Cafe yang Suka Minum Minuman Keras. Jurnal Bimbingan dan Konseling Islam 03/02 (2013). Fakultas Dakwah IAIN Sunan Ampel Surabaya.

M. Nur Ghufron dan Rini Risnawati, S. 2010. Teori-teori Psikologi. Yogjakarta: Ar-Ruzz Media.

Ni Komang Sri Yuli Windari Natih, I Ketut Dharsana, Kadek Suranata. Penerapan Konseling Rasional Emotif Dengan Teknik Role Playing Untuk Meningkatkan Keterbukaan Diri (SelfDisclosure) Siswa Kelas X Mia 3 SMA Negeri 2 Singaraja. E-Journal Undiksa Jurusan Bimbingan Konseling 2/1 (2014).

R.Esty. Efektifitas Konseling Rasional Emotif dengan Teknik Relaksasi untuk Membantu Siswa Mengatasi Kecemasan Menghadapi Ujian. Jurnal Pusat Keberbakatan Fakultas Psikologi U.I Edisi Februari (2008).

Sugiyono. 2012. Metode Penelitian Kuantitatif, Kualitatif, dan R\&D. Bandung: Alfabeta.

Sunanto Juang, Takeuchi, dan Nakata, Hideo. 2005. Pengantar Penelitian dengan Subjek Tunggal. Japan: Criced University of Tsukuba.

W.Andhika Fajar, D.Rachmy. Pengaruh Pelatihan Rasional Emotif Perilaku terhadap Penurunan Perilaku Kecurangan Akademik Siswa. Jurnal Intervensi Psikologi 8/1 (2016).

World Health Organization. 2001. International Clasification Functioning Disability at Health. Geneva: WHO Library Cataloguing. 